\title{
ISO-IMMUNIZATION BY RARE Rh-ANTIGENS AS A CAUSE OF HAEMOLYTIC DISEASE OF THE NEWBORN AND TRANSFUSION REACTIONS
}

\author{
BY \\ J. J. van LOGHEM AND M. v. d. HART \\ From the Blood Grouping Department of the Central Laboratory of the Netherlands Red Cross Blood \\ Transfusion Service
}

(RECEIVED FOR PUBLICATION, APRIL, 1949)

It is well known that $\mathrm{Rh}$ antibodies develop in persons who are nearly always $\mathrm{Rh}$-negative, either as a result of immunization during pregnancy, or as a result of repeated transfusions when $\mathbf{R h}$-positive cells are given to $R h$-negative recipients.

During the last two and a half years we have had an opportunity to study 885 families in which the mothers were immunized by pregnancy. Nearly all these cases were caused by immunization to the $D\left(R h_{0}\right)$ antigen; in some instances, however, antibodies against the $\mathrm{C}\left(\mathrm{rh}^{\prime}\right)$ or $\mathrm{E}\left(\mathrm{rh}^{\prime \prime}\right)$ antigens were developed as well.

Of the 13 blood transfusion reactions due to $\mathbf{R h}$ antagonism, all but two were similarly caused by the most important of the $R h$ antigens, the $D$ or $R h_{0}$ antigen, which was lacking in the recipient.

In the literature only a few cases are reported, in which $R h$ antigens other than $D\left(R_{h}\right)$-that is to say the $C, E, c, d$, or e antigens-have been found to be the only cause of $\mathrm{Rh}$ immunization. In this paper we propose to give details of the few exceptional cases due to immunization to these rarer antigens, and to mention at the same time the possibility of producing antibodies against them by artificial immunization.

\section{Immunization Due to the $\mathbf{E}\left(\mathrm{rh}^{\prime \prime}\right)$ Antigen}

Case 1 (K.F.).-The first child, born in 1934, died seven weeks after birth from gastro-intestinal infection. In 1938 a full-term normal infant was delivered. This was followed by a pregnancy in 1946, which terminated with the birth of a seven-months stillborn foetus. In 1947 a full-term child was born. This child, however, died two days after delivery, without icterus but with symptoms of cerebral lesions (kernicterus ?).

Serological tests gave the following results:

Father's cells: $O$ M P Rh-positive, subtype $\mathrm{cDE}$ $\left(\mathrm{Rh}_{\mathbf{2}}\right)$.
Mother's cells: $\mathrm{O} N$ pp Rh-positive, subtype $\mathrm{CDe}\left(\mathrm{Rh}_{1}\right)$.

Infant's cells: $\mathrm{O}$ MN Rh-positive, genotype $\mathrm{CDe} / \mathrm{cDE}\left(\mathrm{Rh}_{1} \mathrm{Rh}_{2}\right)$.

In the mother's serum a pure antibody, type anti-E (anti-rh"), was present, of titre $1: 8$ in saline as well as in albumin. The same titre was found by means of the indirect Coombs test.

Case 2 (K.).-The first two children were healthy. The third child shortly after birth showed symptoms of a mild icterus, but developed quite normally. The fourth child was brought to hospital when six weeks old. The paediatrician (Bakx, 1949) found a hepatosplenomegaly. The haemoglobin was $43 \%$. No nucleated red cells were found in the blood smear.

Although the mother was group $\mathrm{O}$ Rh-positive, the infant's group $\mathbf{O} \mathbf{R h}$-positive red cells were strongly agglutinated by the serum of the mother.

Serological tests gave the following results:

Father's cells: A Rh-positive, $\mathrm{CDe} / \mathrm{cDE}\left(\mathrm{Rh}_{1} \mathbf{R h}_{2}\right)$.

Mother's cells: O Rh-positive, CDe/CDe $\left(R_{1} h_{1} h_{1}\right)$.

First child: A Rh-positive, $\mathrm{CDe} / \mathrm{CDe}\left(\mathrm{Rh}_{1} R \mathrm{Rh}_{1}\right)$. Second child: $O R h$-positive, $C D e / c D E\left(R h_{1} R h_{2}\right)$. Third child: $O$ Rh-positive, $\mathrm{CDe} / \mathrm{CDE}\left(\mathrm{Rh}_{1} \mathrm{Rh}_{2}\right)$.

Affected baby: $O$ Rh-positive, CDe/cDE $\left(\mathrm{Rh}_{1} \mathbf{R h}_{\mathbf{2}}\right)$.

In the maternal serum a pure antibody of the type anti-E (anti-rh") was present: titre in saline 1:16; titre in albumin $1: 64$.

Cases similar to the two above-mentioned examples have been described by Rice and Watson (1948), Race (1946), and Dick (1947).

Clearly iso-immunization during pregnancy by the $E\left(\mathrm{rh}^{\prime \prime}\right)$ antigen alone is very exceptional.

\section{Immunization Due to the $\mathbf{C}$ (rh') Antigen}

Case 3 (B.L.).- The first child, born in January, 1943, was normal, but a second pregnancy terminated with the birth of a full-term, stillborn child in July, 1945. A third pregnancy ended with the birth of a six-months hydropic foetus in June, 1946. In August, 
1947, a baby was born with mild symptoms of erythroblastosis foetalis. This child was treated by exchange transfusion and developed quite normally, although jaundice persisted for several weeks.

Serological tests:

Father's cells: O Rh-positive, CDe/Cde ( $\left.R h_{1} r^{\prime}\right)$. Mother's cells: A Rh-negative, cde/cde (rhrh).

First child: A Rh-positive, CDe/cde ( $\left.\mathrm{Rh}_{1} \mathrm{rh}\right)$.

Affected infant: O Rh-positive, Cde/cde (rh'rh).

By repeated examinations it was confirmed that the child's cells belonged to the genotype Cde/cde (rh'rh), and that the absence of reaction with anti-D serum was not due to the presence of a weak $D$ or $D^{u}$ antigen, which might have been overlooked early in life. In the mother's serum anti-C was present at a titre of $1: 8$, and anti-D at $1: 32$; both antibodies were of the incomplete type. The presence of the anti-D antibody may be explained by previous immunizations with $D$ antigen. There is no direct proof that the difference in clinical picture between the last-born infant (only mildly affected) and the previous children (severely affected) was the result of a difference in the titre of antibodies, or due to the fact that the child possessed only antigen $C$. It must be added that we have never found a direct relation between the type or titre of antibodies and the clinical picture, although in general a high or increasing titre of incomplete antibodies, type anti-D, is often associated with a severe form of the disease.

As far as we know, only a few examples of erythroblastosis foetalis due to the presence of the antigen $\mathrm{C}\left(\mathrm{rh}^{\prime}\right)$ alone have been described. Waller, Levine, and Garrow (1944) found a case of erythroblastosis foetalis, in which the mother's red cells belonged to group $A_{1}, c D E\left(R h_{2}\right)$, the infant's red cells to $A_{1}, C D e\left(R h_{1}\right)$, and an antibody of the type anti-C ( $\left.\mathrm{rh}^{\prime}\right)$ was found in the maternal serum. Two other cases are reported by Tisdale (1949) and by Drummond (1948).

\section{Immunization Due to the $\mathbf{C W}^{\mathbf{W}}\left(\mathrm{rh}^{\prime \prime}\right.$ ') Antigen}

Erythroblastosis foetalis due to the allelomorph $\left.\mathrm{CW}^{\mathrm{W}}\left(\mathrm{rh}^{\prime \prime}\right)^{\prime}\right)$ is exceedingly rare. The antigen $\mathrm{CW}^{\mathrm{W}}$ was discovered by Callender and Race in 1946, and the first case of $\mathrm{CW}_{-} \mathrm{C}$ antagonism causing erythroblastosis foetalis was described by Lawler and van Loghem (1947).

The infant's red cells belonged to the genotype $C^{w} \mathrm{De} / \mathrm{CDe}\left(\mathrm{Rh}_{1}, \mathrm{w}^{\mathrm{R}} \mathrm{h}_{1}\right)$, and the mother's cells to the genotype $C D e / c d e\left(R_{1} r h\right)$. In the maternal serum a pure anti-CW was present with a titre in saline of $1: 2$, and $1: 128$ in albumin, as well as by means of the indirect Coombs test. A second case of haemolytic disease of the newborn caused by $\mathrm{CW}^{\mathrm{W}} \mathrm{C}$ antagonism has been reported by Broman (1948).

The rare occurrence of erythroblastosis foetalis as a result of iso-immunization by $\mathrm{CW}^{\mathrm{W}}-\mathrm{C}$ antagon- ism may be explained by the low frequency of this antigen, $2.5 \%$ in England and $4.2 \%$ in Holland.

\section{Immunization Due to the c(hr') Antigen}

The antigen $\mathrm{c}\left(\mathrm{hr}^{\prime}\right)$ is responsible for rather a large number of cases of haemolytic disease of the newborn. The corresponding antibody anti-c (anti-hr') was discovered almost simultaneously in 1943 by Levine and Race and Taylor in $\mathrm{Rh}$-positive women.

In our material we have found four cases of erythroblastosis foetalis due to iso-immunization in pregnancy to the antigen $\mathrm{c}\left(\mathrm{hr}^{\prime}\right)$. The genotypes of the father's cells were cde/cde (rhrh), $\mathrm{CDe} / \mathrm{cde}\left(\mathrm{Rh} \mathrm{h}_{1} \mathrm{rh}\right)$, or $\mathrm{cDE} / \mathrm{cde}\left(\mathrm{Rh} \mathrm{h}_{2} \mathrm{rh}\right)$, and that of the mother's cells CDe/CDe (Rh. Rh.). Pure antibodies of type anti-c (anti-hr') in the complete and/or incomplete form were present in the maternal sera.

The sera were also tested with Cde/Cde ( $\left.\mathrm{rh}^{\prime} \mathrm{rh}^{\prime}\right)$ cells in saline, albumin, and with the indirect Coombs test, but an antibody of type anti-d was never found. The antigenic power of the d-antigen must be very weak, for there is an equal chance of producing anti-d as well as anti-c.

Brief histories of these pregnancies follow.

Case 5 (H.). - The first case in Holland was serologically examined and described in detail by Van Bolhuis (1948).

Out of this marriage of father, group $\mathrm{O} \mathrm{cDE} / \mathrm{cde}$ $\left(R h_{2} r h\right)$, and mother, group $A C D e / C D e\left(R h_{1} R h_{1}\right)$, 12 children were born. All of them developed jaundice shortly after birth, and three of them died, the third child from bleeding from the umbilical cord and the seventh child half an hour after birth, with jaundice and ascites. The ninth pregnancy ended with the birth of twins; one of them was very jaundiced and survived only two days, the other one was more mildly affected, although with a strong erythroblastaemia, and developed quite normally. The tenth child was also only mildly affected, but the eleventh now has the sequelae of kernicterus. The last child, born in 1948, was treated with exchange transfusion and developed quite normally.

In the maternal serum an antibody type anti-c (anti-hr') was found at a titre of $1: 64$ in saline and i : 128 in albumin.

Case 6 (v.S.). - In this family, after two normal children in 1939 and 1944, an infant was born with symptoms of a congenital haemolytic anaemia. The haemoglobin level was $40 \%$ and erythrocytes $1,860,000$ per c.mm. There was no jaundice and no hepatosplenomegaly.

Father's cells : $\mathrm{O}$ cde/cde (rhrh).

Mother's cells : $O \mathrm{CDe} / \mathrm{CDe}\left(\mathrm{Rh}_{1} \mathrm{Rh}_{1}\right)$.

Infant's cells : $O \mathrm{CDe} / \mathrm{cde}\left(\mathrm{Rh}_{1} \mathrm{rh}\right)$.

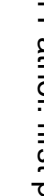


In the maternal serum an antibody type anti-c (anti-hr') was present, at a titre of $1: 16$, in the incomplete form only.

Case 7 (D.). - The history of this patient's pregnancies is marked by a number of stillbirths, with pregnancies terminating in the fifth, third, fifth, sixth, sixth, and sixth months. A living child was never born.

Father's cells : A cde/cde (rhrh).

Mother's cells : O CDe/CDe $\left(R h_{1} R h_{1}\right)$.

An incomplete antibody type anti-c was present: titre in albumin 1:64; in saline, negative.

Case 8 (V.). - The first pregnancy ended in 1942 in a stillbirth, the second resulted in the birth of a normal child in 1943. In 1944 a premature stillborn child was born, $5 \frac{1}{2}$ months old. A child born in 1947 survived, but was jaundiced after birth. In 1948 the last child was born three weeks before term. This infant was very jaundiced and showed symptoms of kernicterus. Unfortunately it was treated with Rh-negative (cde/ cde) $\mathrm{O}$ blood. It survived, however, and three months after birth its blood was investigated. The mother was found to belong to group $A$ CDe/CDe $\left(R h_{1} R h_{1}\right)$, the father to group $A C D e / c d e\left(R_{1} r h\right)$, and the infant to group $\mathrm{O} \mathrm{Cde} / \mathrm{cde}\left(\mathrm{Rh}_{1} \mathrm{rh}\right)$. In the maternal serum an antibody type anti-c was found, titre in saline $1: 2$, in albumin $1: 16$.

As may be concluded from the cases already described and Case 9, the c-antigen is a strong antigen compared with $\mathrm{C}$ and $\mathrm{E}$. The frequency of iso-immunization due to the c-antigen in haemolytic disease of the newborn forms a striking contrast to the infrequency of immunization by $\mathrm{C}$ and $\mathrm{E}$.

\section{Blood Transfusion Reactions Due to Differences in Rh Type}

Blood transfusion reactions due to differences in $\mathrm{Rh}$ type between the recipient and the donor are rarely encountered. One of the most important reactions is due to transfusion of Rh-negative blood to homozygous $\mathrm{Rh}$-positive recipients.

Wiener (1948) reported two cases of transfusion reactions due to the presence of the iso-antibodies anti-c (hr'). Other cases have been reported by Speck and Sonn (1945), Sussmann (1947), and by Callender and Race (1946).

We have encountered one case of a haemolytic transfusion reaction due to immunization by this antigen in a woman who was previously immunized by pregnancy.

Case 9 (V. de W.). - This woman received a blood transfusion for anaemia six days after delivery of her ninth child. Her haemoglobin was $43 \%$. When about $50 \mathrm{ml}$. of blood had been given a severe haemolytic reaction developed, and the transfusion was immedi- ately stopped. The red cells of the donor were agglutinated by the serum of the patient after 15 minutes' incubation at $37^{\circ}$. Further investigations of this reaction showed:

Patient: A CDe/CDe $\left(R h_{1} R h_{1}\right)$.

Donor: A CDe/cDE $\left(\mathrm{Rh}_{1} \mathrm{Rh}_{2}\right)$.

In the serum an iso-antibody of the type anti-c (anti-hr') was present, agglutinating in saline as well as in albumin (titre $1: 512$ ). The patient's husband belonged to group $A \mathrm{cDE} / \mathrm{cde}\left(\mathrm{Rh}_{2} \mathrm{rh}\right)$, and four of the children to group $\mathrm{O} \mathrm{CDe} / \mathrm{cde}, \mathrm{A} \mathrm{CDe} / \mathrm{cde}$, $\mathrm{O} \mathrm{CDe} / \mathrm{cde}$, and $\mathrm{A} \mathrm{CDe} / \mathrm{cDE}$ respectively.

It was remarkable that the history of pregnancies did not show striking evidence for erythroblastosis foetalis. Only one of the nine children, the eighth, born in 1945, was stillborn. The course of all the other pregnancies was quite normal. The children were delivered at full term and did not show any symptoms of haemolytic disease. Even the last child, born six days before the transfusion, was quite healthy without the slightest symptoms of anaemia or jaundice. Unfortunately it was impossible to perform haematological investigations shortly after birth, but undoubtedly the antibody anti-c must have been present in the maternal serum, and presumably in the blood of the last-born child without affecting it, although its blood group was $\mathrm{A} \mathrm{CDe} / \mathrm{cDE}$. The woman had never been transfused before, neither had she received intramuscular injections of blood. All the children probably stimulated the production of anti-c (anti-hr'), for the antigen $c$ in the blood cells of the father was present in the homozygous form, cDE/cde.

The antibody anti-d was detected by Diamond (1946) and later reported by Hill, Haberman, Everist, and Davenport (1948). It has never been encountered in the pure form, but only in combination with anti-c.

The antibody anti-e (anti-hr") was first discovered by Mourant (1945) in a patient of the genotype cDE/cDE $\left(R h_{2} R h_{2}\right)$ who had received multiple transfusions. Recently Wiener and Peters (1948) have described a second example resulting from immunization by blood transfusion, and Moullec (1948) has reported a third case in a 12-year-old girl, also due to multiple transfusions; in this case anti-e was found together with anti-C. There is no example of iso-immunization in pregnancy by this antibody.

We have never encountered the antibody type anti-d (anti-Hr ${ }_{0}$ ) and anti-e (anti-hr") either as a result of pregnancies or of transfusions. Transfusion reactions due to differences in subtypes of $\mathrm{Rh}$-positive blood between donor and recipient are likewise exceedingly rare. The only instance we have encountered was of a patient of blood group $A M N$ cDe $\left(R_{0}\right)$. The scanty clinical 
data available concerning this patient are presented below.

Case 10.- J., 23 years old, was wounded by bomb splinters in July, 1947, and received four transfusions without any reaction. The patient was treated in 1948 with blood transfusions and penicillin for subacute bacterial endocarditis which had developed as a result of local lesions in the heart caused by bomb splinters. Seven transfusions of a pint of blood were given in a period of about five weeks. The second transfusion was followed by chills, and so was the fourth transfusion. A rather severe febrile reaction also followed the last transfusion, but there was no positive evidence of a haemolytic reaction (no haemoglobinuria or jaundice).

Patient's blood cells: A MN cDe $\left(\mathrm{Rh}_{\mathrm{t}}\right)$.

Donor's blood cells: A MN CDe/cDE $\left(R h_{1} R h_{2}\right)$.

It will be seen from Table $I$ that all the reactions were caused by cDE blood.

TABLE I

Case 10: Reactions to Transfusion

\begin{tabular}{|c|c|c|c|}
\hline Date & $\begin{array}{c}\text { Transfusion } \\
\text { No. }\end{array}$ & Reaction & $\begin{array}{c}\text { Donors } \\
\text { Blood Group }\end{array}$ \\
\hline $\begin{array}{r}\text { July } 1947 \\
10-9-48 \\
14-9-48 \\
17-9-48 \\
21-9-48 \\
26-9-48 \\
6-10-48 \\
21-10-48\end{array}$ & $\begin{array}{l}4 \text { transfusions } \\
\text { First } \\
\text { Second } \\
\text { Third } \\
\text { Fourth } \\
\text { Fifth } \\
\text { Sixth } \\
\text { Seventh }\end{array}$ & $\begin{array}{l}\text { No reaction } \\
\text { Çhill ", } \\
\text { No reaction } \\
\text { Chill } \\
\text { No reaction } \\
\text { Çhill " }\end{array}$ & $\begin{array}{l}A \operatorname{cDE}\left(\mathrm{Rh}_{2}\right) \\
\text { A CDe }\left(\mathrm{Rh}_{1}\right) \\
\mathrm{A} \operatorname{cDE}\left(\mathrm{Rh}_{2}\right)\end{array}$ \\
\hline
\end{tabular}

After the last transfusion a pure antibody type anti-E (anti-rh") was present in the patient's serum, only reacting in albumin at a titre of $1: 16$.

Race (1946) has found several cases of transfusion reactions due to the $\mathrm{E}$ antigen.

TABLE II

EXPerimental Formation OF PURE ANTIBOdy TyPe ANTI-C ${ }^{w}$

\begin{tabular}{|c|c|c|c|c|}
\hline \multirow{2}{*}{\multicolumn{2}{|c|}{$\begin{array}{c}\text { Date of } \\
\text { Injection and } \\
\text { Serial No. }\end{array}$}} & \multirow{2}{*}{$\begin{array}{l}\text { Amount of } \\
\text { O C Cells } \\
\text { Injected } \\
\text { (ml.) }\end{array}$} & \multicolumn{2}{|c|}{$\begin{array}{l}\text { Titres of Antibodies } \\
\left.\text { (Anti-C }{ }^{*}\right)\end{array}$} \\
\hline & & & Saline & Albumin \\
\hline $\begin{array}{r}26.4 .48 \\
5.8 .48 \\
16.8 .48 \\
19.8 .48 \\
23.8 .48 \\
25.8 .48\end{array}$ & $\begin{array}{l}1 \mathrm{st} \\
21 \mathrm{st} \\
22 \mathrm{nd} \\
23 \mathrm{rd} \\
24 \mathrm{th}\end{array}$ & $\begin{array}{l}0 \cdot 5 \\
0 \cdot 5 \\
1 \cdot 0^{*} \\
1 \cdot 0\end{array}$ & $\begin{array}{l}1: 2 \\
1: 16 \\
1: 32\end{array}$ & $\begin{array}{l}1: 8 \\
1: 8 \\
1: 16 \\
1: 64 \\
1: 128\end{array}$ \\
\hline
\end{tabular}

* $0.5 \mathrm{ml}$. of typhoid vaccine (triplovaccin diluted 1:3) given intramuscularly.

\section{Antibody Formation Due to Artificial Immunization}

In previous articles we reported the production of the rare antibodies anti-C and anti-E as a result of frequent immunization with small quantities of Cde and cdE cells in $R$ h-negative volunteer donors. The influence of heterospecific immunization on the production of antibodies against the injected antigen $\mathrm{C}$ and $\mathrm{E}$ was described. By this means we succeeded in producing two sera with anti-C and one with anti-E, the last one without the injection of heterospecific antigens.

After this method was proved to be successful we tried to make the rare antibody anti-CW in the same way. Three of our volunteer donors were injected with cells of the $R h$ group $C^{W} D e / c d e$. Injections of $0.5 \mathrm{ml}$. of a $50 \%$ suspension of these cells were given twice a week. The $R h$ groups of the donors were $\mathrm{CDe} / \mathrm{cde}$. As will be seen from Table II one of the donors (Group O MN $\mathrm{CDe} /$ cde) reacted with the formation of a pure antibody type anti-CW. It is highly probable that the titre $1: 8$ found after the twenty-first and twenty-second injections was increased by the administration of typhoid vaccine injected intramuscularly. After 24 injections the titre in saline was $1: 32$ and in albumin $1: 128$. At this time the donor was bled and the immunization procedure stopped.

\section{Summary}

In 885 cases of $\mathrm{Rh}$ iso-immunization during pregnancy, the antigen $D$ was almost invariably concerned. In these cases the mother was D-negative and the infant D-positive, and the mother formed anti-D, with or without anti-C or anti-E. In one case an infant of genotype Cde/cde was affected by anti-C in its mother's serum.

In eight exceptional cases the mother was Dpositive and formed anti-c (4 cases), anti-E (2 cases), or anti-CW (1 case).

Similarly, of 13 blood transfusion reactions due to $R h$ incompatibility, all but two were caused by the formation of anti-D by a D-negative recipient. In the two exceptional cases, anti-c and anti-E were concerned.

The rare antibody anti-CW was produced by one out of three volunteers who were given repeated intravenous injections of $\mathrm{CW}^{\mathrm{W}}$ blood.

We wish to thank the following clinicians who have sent specimens of blood and details of the cases: C. J. A. Bakx, H. Bauer, J. H. van Bolhuis, P. K. de Haas, B. J. Mansens, J. M. Soeters, W. Vetter. 


\section{REFERENCES}

Bakx, C. J. A., and Vooren, M. van de (1949). Ned. Tijdschr. Geneesk., 93, 261 .

Bosch, C. van den (1948). Nature, Lond., 162, 781.

Broman, B. (1948). Personal communication.

Callender, S. T., and Race, R. R. (1946). Ann. Eugen., 13, 102.

Diamond, L. K. (1946). "Physicotechnical and Immunological Character of Rh Antibodies." Paper read at International Haematology and $\mathbf{R h}$ Congress, Dallas, Texas. (Unpublished data.)

Dick, D. S. (1947). Brit. med. J., $2,95$.

Drummond, R. J. (1948). Quoted Med. Res. Coun. Memorandum No. 19, London.

Hill, J. M., Haberman, S., Everist, B. W., and Davenport, J. W. (1948). Blood, 3, 682.

Lawler, S. D., and van Loghem, J. J. (1947). Lancet, 2, 545.
Levine, Ph. (1943). J. Pediat., 23, 656.

Moullec, J. (1948). C.R. Soc. Biol., Paris, 142, 583.

Mourant, A. E. (1945). Nature, Lond., 155, 542.

Race, R. R. (1946). Brit. med. Bull., 4, 188.

- and Taylor, G. L. (1943). Nature, Lond., 152, 300.

Rice, W. G., and Watson, R. G. (1948). Amer. J. clin. Path., 18, 598.

Speck G., and Sonn, E. B. (1945). Amer. J. Obstet. Gynec., 49, 273.

Sussmann, L. N. (1947). Amer. J. clin. Path., 17, 643.

Tisdale (1949). Referred to by M. M. Pickles, Haemolytic Disease of the Newborn. Oxford.

Van Bolhuis, J. H. (1948). Maandschr. Kindergeneesk., 16, 262. Waller, R. K., Levine, P., and Garrow, I. (1944). Amer. J. clin. Path., 14, 577.

Wiener, A. S. (1948). J. Lab. clin. Med., 33, 985.

- - and Peters, H. R. (1948). Amer. J. clin. Path., 18, 533.

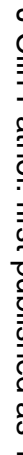

年 